\title{
Reversible Heat Stress-related Loss of Phosphorylated Alzheimer-type Epitopes in Tau Proteins of Human Neuroblastoma Cells
}

\author{
Marie Fang Chiang, Wan-Kyng Liu, and Shu-Hui Yen \\ Department of Pathology, Albert Einstein College of Medicine, Bronx, New York 10461
}

\begin{abstract}
Human neuroblastoma cells, LAN, were used to study the phosphorylation and dephosphorylation of tau proteins. These cells contained mainly a form of tau comparable to fetal brain tau in molecular weight ( $55 \mathrm{kDa}$ ). Neuroblastoma tau reacted with antibodies that recognize epitopes spanning the whole tau molecule (E-1, Alz50, Tau-1, and Tau46), and antibodies (PHF-1, NP8, and T3P) that recognize hyperphosphorylated tau (PHF-tau) in Alzheimer's disease (AD) brains. Exposure of the cells to $45^{\circ} \mathrm{C}$ heat stress resulted in dephosphorylation of the epitopes recognized by PHF-1, NP8, and T3P. Transfer of the heat-stressed cells to $37^{\circ} \mathrm{C}$ led to rephosphorylation of the dephosphorylated epitopes. Cells that had been treated with okadaic acid (OA), regardless of whether they were subsequently subjected to heat stress or heat stress and recovery, all contained tau with a molecular weight similar to that of control cells. These tau proteins, similar to tau in control cells, also reacted with antibodies to phosphorylated epitopes. However, unlike the tau from control or heat-stressed cells, the OA-treated and heatstressed tau had decreased reactivity with Tau-1. Alteration of Tau- 1 immunoreactivity has been reported to be an early event in AD neurodegeneration. The reduction of Tau-1 immunoreactivity observed in OA-treated samples could be restored by incubation of electroblots of isolated tau with alkaline phosphatase, indicating an induction of the Tau-1 epitope phosphorylation by OA. The results of our studies suggest that neuroblastoma cells may contain phosphatases/kinases that are comparable to that in $A D$, and that culture cells may be used for studying the mechanisms involved in AD neurofibrillary formation.
\end{abstract}

[Key words: human neuroblastoma cells, heat stress, okadaic acid, phosphorylation, dephosphorylation]

Microtubule-associated proteins, tau, in adult brains are heterogeneous in molecular weight and isoelectric charge (Cleveland ct al., 1977; Ksiczak-Rcding ct al., 1988). These proteins, detected by gel electrophoresis as five or six polypeptides ranging between 50 and $60 \mathrm{kDa}$, are encoded by six transcripts generated

Received Dec. 21, 1992; revised May 4, 1993; accepted May 20, 1993.

Antibodies Alz50, NP8, and PHF-1 were generously provided by Dr. Peter Davies, Albert Einstein College of Medicine. Tau46 and T3P were kindly provided by Dr. Virginia Lee, and Tau-1 by Dr. Lester I. Binder. We thank Drs. Hanna Ksiezak-Reding and Dennis Dickson for their comments on the manuscript. This work was supported by NIH Grants NS07098 (M.F.C.), AG01 136, and AG04145 (S.-H.Y.).

Correspondence should be addressed to Shu-Hui C. Yen, Department of Pathology, F-538, Albert Einstein College of Medicine, 1300 Morris Park Avenue, Bronx, NY 10461.

Copyright (c) 1993 Society for Neuroscience $0270-6474 / 93 / 134854-07 \$ 05.00 / 0$ from a single gene by alternative gene splicing (Goedert et al., 1989; Himmler, 1989; Himmler et al., 1989; Goedert and Jakes, 1990). Three of the tau transcripts contain three tandem repeats in the carboxy (C)-terminal half, which are considered to be the microtubule binding domain. The remaining transcripts contain four repeats. Tau transcripts also differ from each other by the presence or absence of 29 or 58 amino acid inserts located in the amino (N)-terminal region (Goedert et al., 1989; Goedert and Jakes, 1990). Besides alternative gene splicing, heterogeneity of adult tau is due to phosphorylation (Lindwall and Cole, 1984). Purified tau contains about 2 mol of phosphate/mol protein, which can be phosphorylated in vitro by different kinases, including protein kinase A (Yamamoto ct al., 1985), protein kinase C (Baudier and Cole, 1987b), casein kinase II (Diaz-Nido et al., 1988), calcium/calmodulin kinase Il (Yamamoto et al., 1983; Baudier and Cole, 1987a), tubulin-stimulated kinase (Ishiguro et al., 1988), ATP.Mg-dependent protein phosphatase activator, $F_{A}$ (Yang et al., 1991), and microtubule-associated protein (MAP) kinase (Drews et al., 1992). Phosphorylated tau is a substrate for in vitro dephosphorylation by alkaline phosphatase (Lindwall and Cole, 1984), acid phosphatase, and protein phosphatases 1, 2A, and 2B (Goto et al., 1985; Yamamoto et al., 1988).

Tau proteins from fetal brains are smaller in size than those from adult brains. Fetal human tau proteins are polypeptides of molecular weight 50-55 kDa (Liu et al., 1992). These polypeptides are encoded by transcripts with three tandem repeats and without N-terminal inserts (Goedert et al., 1989).

Hyperphosphorylated tau proteins are a major component of paired helical filaments (PHF), which are abnormal structures characteristic of degenerating neurons in Alzheimer's disease (AD) (Kidd, 1963; Terry et al., 1964; Wisniewski et al., 1976; Braak et al., 1986). These modified tau proteins, named PHFtau or $\mathrm{A68}$, differ from normal adult tau protein in the extent and site(s) of phosphorylation (Grundke-Iqbal et al., 1986; Kosik et al., 1988; Greenberg and Davies, 1990; Ksiezak-Reding et al., 1990b, 1992; Brion et al., 1991; Lee et al., 1991; Liu et al., 1991). Several subregions (or sites) of the tau molecule have been reported to be phosphorylated in PHF-tau, but not in normal adult tau. These subregions are recognized by antibodies E-2 (Liu et al., 1993), Tau-1 (Wood et al., 1986; Kosik et al., 1988), PHF-1 (Greenberg et al., 1992), TP30 (Brion et al., 1991), T3P (Lee et al., 1991), NP8 (Ksiezak-Reding et al., 1987), antiptau1, and anti-ptau2 (Kanemaru et al., 1992). With the exceptions of the E-2, TP30, and Tau-1 epitopes, all of the phosphorylated sites are at the C-terminal half of the tau molecule. Of the phosphorylated sites, those that are recognized by PHF1, anti-ptau1, or anti-ptau2 also have been detected by immunoblotting in tau from fetal brains (Greenberg et al., 1992; 
Kanemaru et al., 1992). These findings raise the possibility that the activation of kinases or inhibition of phosphatases unique to $\mathrm{AD}$ and fetal neurons or the imbalance of normal kinases/ phosphatases in $\mathrm{AD}$ tissue leads to hyperphosphorylation of PHF-tau. The significance of the reexpression of fetal proteins in the pathogenesis of $\mathrm{AD}$ is also supported recently by the finding of a $70 \mathrm{kDa}$ fetal protein unrelated to tau and phosphorylated MAP5 in Alzheimer brains (Hasegawa et al., 1990; Morishima-Kawashima et al., 1991).

To understand the dynamics of tau phosphorylation and also the mechanism(s) involved in abnormal phosphorylation of PHFtau, we have subjected cultured human neuroblastoma cells to heat stress and/or okadaic acid (OA), an inhibitor specific to phosphatases 1 and $2 \mathrm{~A}$ (Bialojan and Takai, 1988). Tau proteins were isolated from cultured cells and probed with different tau antibodies. We demonstrated that (1) more than $90 \%$ of the tau proteins in cultured neuroblastoma cells are similar to fetal brain tau in molecular weight and immunochemical properties, (2) neuroblastoma tau shares phosphorylated epitopes with PHFtau, (3) heat stress induces dephosphorylation of neuroblastoma tau, (4) heat stress-induced dephosphorylation occurs at PHF1 , NP8, and T3P epitopes, (5) OA protects tau from heat stressinduced dephosphorylation, and (6) OA induces phosphorylation of tau proteins at the Tau-1 epitope. Our results demonstrate that cultured human neuroblastoma cells may be a source for identification and isolation of enzymes related to the phosphorylation and dephosphorylation of PHF-tau and fetal tau. Furthermorc, these cultured cells may be useful for understanding the mechanisms involved in PHF formation.

\section{Materials and Methods}

Cell culture. LAN cells, obtained originally from Dr. J. L. Beidler (Sloan Kettering Institute, NY), were cultured in $175 \mathrm{~cm}^{2}$ flasks, in an incubator at $37^{\circ} \mathrm{C}$ containing $8 \% \mathrm{CO}_{2}$. The cells were grown in RPMI 1640 medium supplemented with $0.4 \mathrm{~mm}$ serine, $0.4 \mathrm{~mm}$ asparagine, $1 \mathrm{~mm}$ glutamine, $1 \%$ nonessential amino acids, $10 \%$ fetal bovine serum, penicillin (100 $\mathrm{IU} / \mathrm{ml})$, and streptomycin $(100 \mu \mathrm{g} / \mathrm{ml})$.

Heat-shock treatment. The cells were subjected to heat stress at $45^{\circ} \mathrm{C}$ for $1 \mathrm{hr}$. Some cells were harvested immediately, while others were harvested after $1,2,4,6$, or $16 \mathrm{hr}$ of recovery at $37^{\circ} \mathrm{C}$. In some studies, the cells were heat stressed for 15,30 , and $45 \mathrm{~min}$ and then harvested. In other studies, $1 \mu \mathrm{M}$ emetine dihydrochloride (a protein synthesis inhibitor) was added to the cultures before heat stress, or $30 \mathrm{~min}$ before the recovery. The amount of emetine was effective in the inhibition of protein synthesis in LAN cells and other human neuroblastoma cells as well (Casper and Davies, 1989).

Okadaic acid treatment. Cells were treated with $1 \mu \mathrm{M}$ of OA (Moana Bioproducts Inc., $\mathrm{HI}$ ), followed by heat stress at $45^{\circ} \mathrm{C}$ and recovery at $37^{\circ} \mathrm{C}$. In some studies, the cells were treated with $500 \mathrm{nM}, 100 \mathrm{~nm}, 50$ $\mathrm{nm}$, and $10 \mathrm{~nm} \mathrm{OA}$. For controls, OA-treated cells were kept at $37^{\circ} \mathrm{C}$ for 1 and $5 \mathrm{hr}$.

Cell harvesting. The cells were collected in $5.0 \mathrm{ml}$ of $10 \mathrm{~mm}$ Tris$\mathrm{HCl}, \mathrm{pH}$ 8.0, 0.14 м NaCl, I mм EDTA, 0.1 mм phenylmethylsulfonyl fluoride (PMSF), and $0.2 \%$ azide, and recovered by centrifugation at $300 \times g$ for $10 \mathrm{~min}$. They were then lysed in a solution containing 20 mM 2-[N-morpholino]ethanesulfonic acid (MES), pH 6.8, $80 \mathrm{~mm} \mathrm{NaCl}$ $1 \mathrm{~mm} \mathrm{MgCl}$, 2 mM EGTA, $10 \mathrm{~mm} \mathrm{NaH}_{2} \mathrm{PO}_{4}, 20 \mathrm{~mm} \mathrm{NaF}, 1 \mathrm{~mm}$ PMSF, and $10 \mu \mathrm{g} / \mathrm{ml}$ leupeptin, and stored at $-70^{\circ} \mathrm{C}$ or used immediately. In some experiments, additional phosphatase inhibitors were added to the lysis solution mentioned above. These inhibitors include $50 \mathrm{~mm} \mathrm{NaF}$ $25 \mathrm{~mm} \beta$-glycerolphosphate, $0.1 \mathrm{~mm}$ sodium vanadate, and $1 \mu \mathrm{M} O A$. Samples extracted with both conditions showed similar immunoblotting pattern with anti-tau antibodies.

Preparation of tau-enriched fraction. The lysed cell suspensions were homogenized with a Potter-Elvehjem type homogenizer (20 strokes), and centrifuged at $11,000 \times g$ for $15 \mathrm{~min}$. The supcrnatants were removed and mixed with mercaptoethanol (final concentration, $2 \%$ ) and $\mathrm{NaCl}(2 \%)$ for $30 \mathrm{~min}$ at $4^{\circ} \mathrm{C}$. The samples were then boiled for $5 \mathrm{~min}$, followed by centrifugation at $11,000 \times g$ for $15 \mathrm{~min}$. The heat-stable supernatants thus obtained were enriched in tau proteins. In two studies, tau proteins were further purified by treatment with $2.5 \%$ perchloric acid as described before (Lindwall and Cole, 1984; Ksiezak-Reding et al., 1990b). The acid-soluble proteins were precipitated with methanol.

Gel electrophoresis, electroblotting, and immunoblotting. The heatstable or heat and perchloric acid-stable tau preparations were subjected to SDS-polyacrylamide gel electrophoresis (SDS-PAGE) (Laemmli, 1970). The amount of protein in these preparations was determined (Lowry et al., 1951). A similar amount of protein from different experimental conditions was loaded on acrylamide gel. After separation with 10\% SDS-PAGE and electroblotting to nitrocellulose paper, proteins were immunostained with various anti-tau antibodies. The bound immunoglobulins were detected by the avidin-biotin-peroxidase method with a Vectastain ABC kit (Vector Inc.), by a secondary antibody linked to alkaline phosphatase (Calbiochem), or by the chemiluminescent method (Amersham). In some studies the electroblots were double labeled with two anti-tau antibodies. In such instances, Vectastain was used for detecting one antibody, and alkaline phosphatase for the other antibody. The intensity of the immunostaining was determined by scanning the immunoblots with a Schimadzu TLC Scanner.

For studying Tau-1 epitope phosphorylation, a five-tooth comb was used in gel electrophoresis. The electroblot obtained from each lane was divided in halves. One half of the strip was incubated with Escherichia coli alkaline phosphatase $\left(10 \mathrm{IU} / \mathrm{ml}\right.$; Sigma) for $2 \mathrm{hr}$ at $37^{\circ} \mathrm{C}$ in $100 \mathrm{~mm}$ Tris- $\mathrm{HCl}$ buffer, pH 8.1, with $0.1 \mathrm{~mm} \mathrm{ZnCl}_{2}, 1 \mathrm{~mm} \mathrm{MgCl}_{2}, 1 \mathrm{~mm} \mathrm{PMSF}$, and $0.2 \mathrm{~mm}$ dithiothreitol. The other strip was not treated with the enzyme. Both strips were then incubated with Tau-1 antibody. To demonstrate the specificity of alkaline phosphatase, $50 \mathrm{~mm}$ phosphate buffer was mixed with phosphatase in some studies.

Antibodies. Eight tau-reactive antibodies were used, which included monoclonal antibodies Alz50, Tau-1, PHF-1, NP8, and Tau46 and polyclonal antibodies E-1, E-2, and T3P. Alz50 and NP8, provided by P. Davies (Albert Einstein College of Medicine), were raised against AD brain homogenates (Wolozin et al., 1986; Ksiezak-Reding et al., 1987). The Alz50 epitope is phosphate independent (Greenberg et al., 1992) and is located at the N-terminus of tau molecule amino acids (aa) 2-10 (Ksiezak-Reding et al., 1990a; Goedert et al., 1991). The NP8 epitope is phosphate dependent and is present in neurofilament proteins and bovine and rat tau proteins, but not normal adult human tau. E-l and E-2 (Liu et al., 1992) were raised to synthetic peptides corresponding to amino acid residues $19-33$, and $44-55$, respectively, of the longest human tau isoform (Goedert et al., 1989). Tau-1, obtained from L. I. Binder (University of Alabama), recognizes an epitope located at amino acid residues 189-207. The Tau- 1 epitope and some of the E-2 epitopes are more phosphorylated in PHF-tau than in normal tau (Liu et al., 1992). PHF-1 was raised against a relatively soluble population of PHF (Greenberg et al., 1992). This antibody reacts most intensely with PHFtau, less intensely with fetal human tau, and weakly with adult human tau. The PHF-1 epitope is phosphate dependent. T3P was raised against a phosphosynthetic peptide (Lee et al., 1991), whose amino acid sequence corresponds to aa $389-402$ of tau, and the phosphate was at $\mathrm{Ser}^{396}$. The antibody reacts with PHF-tau, but has no reactivity with normal adult tau. Tau46 recognizes an epitope located at the $\mathrm{C}$-end of tau (aa 404-441) (Kosik et al., 1988), which is also shared by microtubule-associated protein 2 (MAP2) (Ksiezak-Reding et al., 1990a). Both T3P and Tau46 were obtained from V. Lee (University of Pennsylvania).

\section{Results}

\section{Tau isoforms in neuroblastoma cells}

Immunoblotting of tau-enriched fractions from LAN cells demonstrated the presence of a major tau-immunoreactive band at $55 \mathrm{kDa}$ region, two minor bands at $53 \mathrm{kDa}$ and $58 \mathrm{kDa}$ (Fig. 1 , lanes marked C), and smaller-molecular-weight bands. The detection of minor tau isoforms depended on the amount of protein loaded on gels. The immunoblots of tau extracted by different lysis solutions were similar.

The $58 \mathrm{kDa}, 55 \mathrm{kDa}$, and $53 \mathrm{kDa}$ bands all reacted with taureactive antibodies that recognize epitopes spanning the entire tau molecule (Alz50, Tau-1, Tau46, and E-1, not shown). These tau proteins also contained phosphorylated epitopes (PHF-1, 
$\underline{\mathbf{C}}$

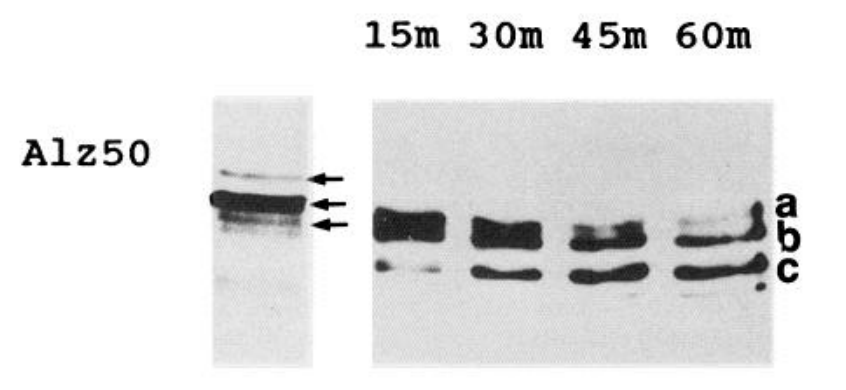

Tau-1
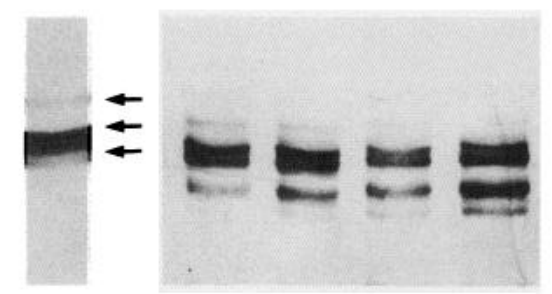

Tau46
Stress

Recovery

$2 \mathrm{~h}$

$4 \mathrm{~h}$

$6 \mathrm{~h}$
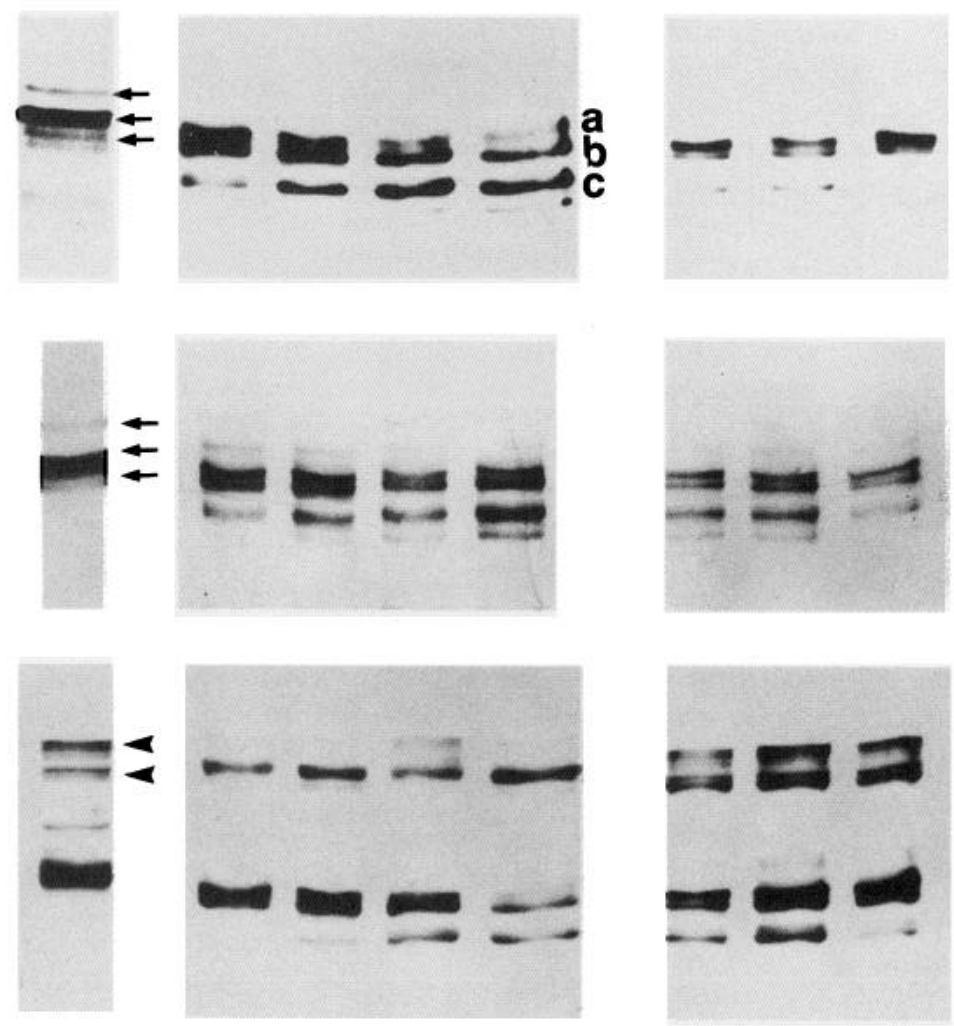

$\underline{\mathrm{c}}_{\mathrm{OA}}$

$\underline{O A+\text { Stress }}$ + Recovery
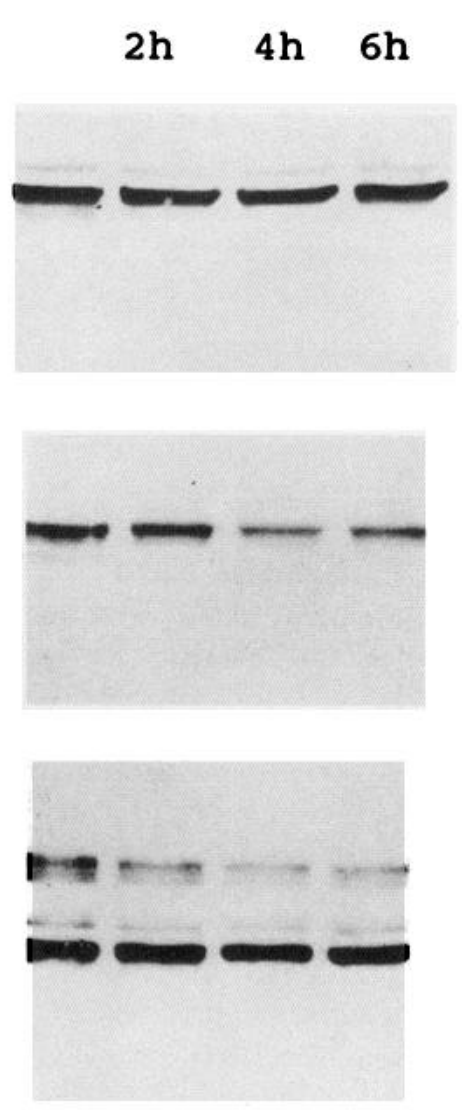

Figure 1. Immunoblotting of a tau-enriched fraction from neuroblastoma cells with Alz50, Tau-1, and Tau46. Samples from untreated cells $(C)$, cells with $15-60 \mathrm{~min}(\mathrm{~m})$ of heat stress at $45^{\circ} \mathrm{C}$, cells with $2-6 \mathrm{hr}(\mathrm{h})$ of recovery from heat stress, and cells treated with $1 \mu \mathrm{M} \mathrm{OA}$ were compared. $C_{O A}$ represents preparations from cells that were treated with OA alone for $5 \mathrm{hr}$. Untreated cells contain tau of molecular weight 58,55 , and 53 $\mathrm{kDa}$ (marked by arrows), and smaller tau fragments. Tau46 reacts with both tau and MAP2C (marked by arrowheads), due to the sharing of a common amino acid sequence. Heat stress resulted in a reduction of tau molecular weight. OA-treated cells contained tau with a molecular weight similar to that of untreated cells. The treatment reduced the reactivity of tau with Tau-1 antibody.

T3P, and NP8) known to be present in PHF-tau (Fig. 2, lanes marked C). The $58 \mathrm{kDa}$ tau differed from other tau bands in reactivity with E-2, an antibody that recognizes a subregion of tau known to be expressed in the $\mathrm{N}$-terminal half of adult brain tau, but not fetal brain tau. Unlike the $58 \mathrm{kDa}$ band, the 55 $\mathrm{kDa}$ and $53 \mathrm{kDa}$ bands were not recognized by E-2 (Fig. 3; compare the blot stained with E-2 with the blot stained with both E-2 and Tau-1). By densitometric scanning of immunoblots stained with Tau-1 or Tau46, we estimated that the 53$55 \mathrm{kDa}$ tau accounted for at least $90 \%$ of the neuroblastoma tau.

Besides tau proteins, Tau46 also reacted with bands at 68 $\mathrm{kDa}$ (Fig. 1, band marked with arrowheads) and above $200 \mathrm{kDa}$ (not shown). These non-tau proteins are probably related to the MAP2 family, since Tau46 has been reported to recognize epitopes shared by tau and MAP2 (Ksiezak-Reding et al., 1990a). NP8 also reacted with proteins of molecular weight higher than tau and different from MAP2 (not shown). The NP8-reactive proteins are most likely phosphoproteins that share epitopes with tau and neurofilament proteins.

\section{Effect of heat stress on the electrophoretic mobility and immunoreactivity of tau}

Incubation of neuroblastoma cells at $45^{\circ} \mathrm{C}$ for $15-60$ min resulted in an increase in the electrophoretic mobility of tau (Fig. 1 , Stress). Instead of detecting tau at the 53-58 kDa region, three or four tau-immunoreactive bands were detected between 55 $\mathrm{kDa}$ and $45 \mathrm{kDa}$. Similar to untreated tau, these polypeptides reacted with antibodies that recognize epitopes at the N-terminus (Alz50, E-1), middle region (Tau-1), and the C-terminus (Tau46) of tau molecule. The samples with longer heat stress proportionally contained more tau with high electrophoretic mobility (Fig. 1; compare band a with bands b and c). The heatstressed tau reacted weakly with E-2, and they were detected as two bands migrating around the $55 \mathrm{kDa}$ region (Fig. 3).

Heat stress changed the immunoreactivity of tau with PHF1, T3P, and NP8 (Fig. 2, Stress). In cells that were heat stressed for $15 \mathrm{~min}$, there was an apparent decrease of the immunoreactivity of tau with antibodies to phosphorylated epitopes. After 30-60 min of heat stress, the immunoreactivity of phosphorylated epitopes was no longer detectable, indicating that the loss of immunoreactivity of phosphorylated epitopes may be due to dephosphorylation. Addition of a protein synthesis inhibitor did not modify the response to heat stress. Also, the inclusion of additional phosphatase inhibitors in the lysis buffer did not alter results (data not shown).

\section{Tau immunoreactivity in cells recovering from heat stress}

Similar to heat-stressed cells, recovering cells also contained three or four undegraded tau polypeptides of 55-45 $\mathrm{kDa}$ that were reactive with Alz50, Tau-1, Tau46, and E-1 (Fig. 2). Recovery was slow; by $16 \mathrm{hr}$ the cells still contained some tau with 

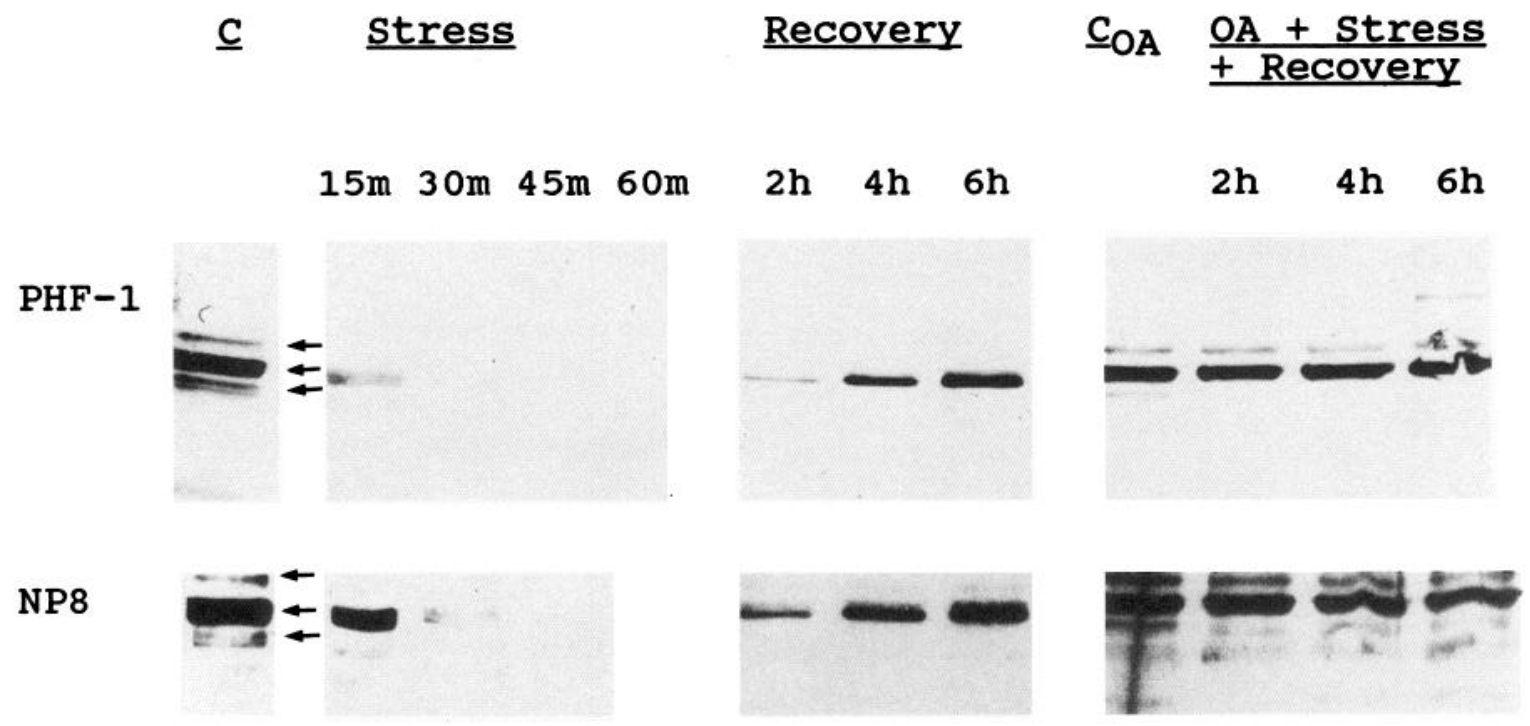

T3P
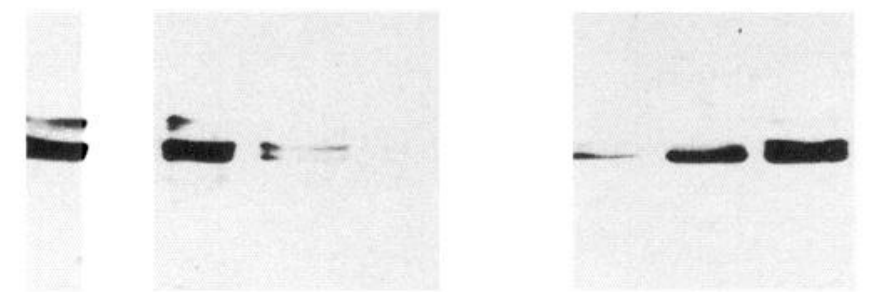

Figure 2. Effect of heat stress, recovery, and OA treatment on the immunoreactivity of neuroblastoma tau to PHF-1, NP8, and T3P. The 58 kDa, $55 \mathrm{kDa}$, and $53 \mathrm{kDa}$ tau proteins (marked by arrows) were recognized by the antibodies. Heat stress for $30-60$ min $(\mathrm{m})$ abolished the immunoreactivity of tau with antibodies to phosphorylated epitopes. During recovery, the tau proteins regained their immunoreactivity. OA treatment protected the cells from heat stress-induced alteration of immunoreactivity to antibodies to phosphorylated epitopes.

molecular weight smaller than that of control cells (data not shown).

Unlike the stressed cells, there was a reappearance of immunoreactivity with PHF-1, T3P, and NP8 in recovering cells (Fig. 2, Recovery). Whether protein synthesis inhibitors were present or not had no effect on the immunoreactivity of phosphate-dependent epitopes. By densitometry, tau with $6 \mathrm{hr}$ of recovery was about 15,12 , and 3 times more immunoreactive with PHF-1, T3P, and NP8, respectively, than tau with $2 \mathrm{hr}$ of recovery. The results indicate that the epitopes dephosphorylated by heat stress can be rephosphorylated during recovery.

\section{$O A$ protects tau from the effect of heat stress}

As shown in Figure 2, OA-treated cells, regardless of whether they were subsequently subjected only to heat stress or to both heat stress and recovery, all contained tau proteins similar to those of control cells in molecular weight and in reactivity with PHF-1, T3P, and NP8. The protection of tau by OA from heat stress was also shown by immunoblotting with antibodies that recognize non-phosphorylated epitopes, Alz50, and Tau46.

Five hundred nanomolar OA was able to block the heat stressinduced changes of tau molecular weight and immunoreactivity (data not shown).

\section{OA treatment induces phosphorylation of the Tau-1 epitope}

OA-treated cells contained tau that were less reactive with Tau-1 antibody than tau proteins from untreated control cells (Fig. 1, $\mathrm{OA}$ ). The $58 \mathrm{kDa}$ band was not stained, and the staining of 55$53 \mathrm{kDa}$ region was weaker than the corresponding region in the control samples (Fig. 1; compare $\mathrm{C}_{\mathrm{OA}}$ with $\mathrm{C}$ ). Tau proteins from 4 or $6 \mathrm{hr}$ recovering cells, as estimated by densitometry, were $70 \%$ less labeled by the Tau- 1 antibody than those from cells after $2 \mathrm{hr}$ recovery. This change was not due to differences in the loading of protein, since both samples contained similar levels of Alz50 and Tau46 immunoreactivity. Instead, it was most consistent with phosphorylation of the Tau-1 epitope (Fig. 4). Tau-1 immunoreactivity of control cells was not changed by

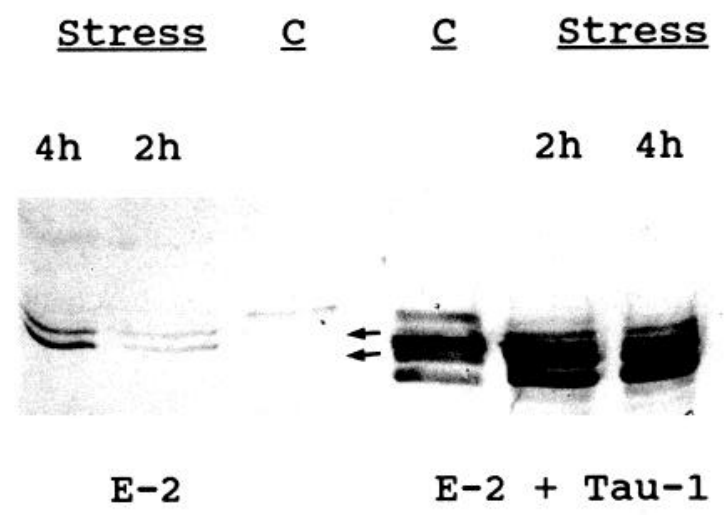

Figure 3. Immunoblots show E-2 binding to the $58 \mathrm{kDa}$ neuroblastoma tau, but not the $55-53 \mathrm{kDa}$ tau. As shown in the right panel, the $55-53 \mathrm{kDa}$ bands (marked by arrows) not detected by E-2 (see left panel) were positive with Tau-1. The electrophoretic mobility of E-2-reactive tau was increased by heat stress $(2,4 \mathrm{hr})$. 


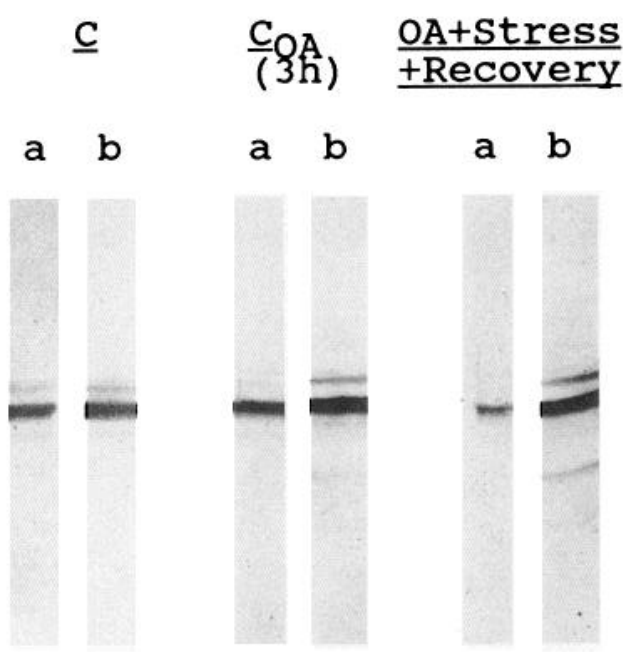

Figure 4. OA treatment induces phosphorylation of the Tau-1 epitope. Electroblots containing tau from untreated cells $(C)$, from cells treated for $3 \mathrm{hr}$ with $\mathrm{OA}\left(C_{O A}\right)$, and from cells with $\mathrm{OA}$, heat stress, and recovery were each cut into two lanes: without alkaline phosphatase treatment $(a)$ and with phosphatase treatment $(b)$. Note that alkaline phosphatase treatment increases the immunoreactivity of OA-treated samples but has very little effect on the sample without OA treatment.

alkaline phosphatase treatment. In contrast, phosphatase treatment enhanced Tau-1 immunoreactivity of proteins from OAtreated control cells (Fig. 4, $\mathrm{C}_{\mathrm{OA}}$ ) by 1.8 -fold, and from cells subjected to OA + heat stress + recovery by 4.7 -fold (Fig. 4). The results indicate that $\mathrm{OA}$ treatment was accompanied by phosphorylation of the Tau-1 epitope. Similar alkaline phosphatase treatment did not alter immunoreactivity of tau proteins with Tau46, an observation that is consistent with the fact that Tau46 is not phosphate dependent (data not shown). The induction of phosphorylation of the Tau-1 epitope was observed in cells as early as $1 \mathrm{hr}$ after OA treatment.

\section{Discussion}

In this study, we demonstrated that cultured human neuroblastoma cells contained tau of molecular weight about $55 \mathrm{kDa}, 53$ $\mathrm{kDa}$, and $58 \mathrm{kDa}$. The $55 \mathrm{kDa}$ and $53 \mathrm{kDa}$ tau had no detectable reactivity with E-2, whereas the $58 \mathrm{kDa}$ tau was reactive with E-2. The $55-53 \mathrm{kDa}$ tau represented more than $90 \%$ of the tau from neuroblastoma cells and was comparable to fetal brain tau in molecular weight and in immunoreactivity with anti-tau antibodies (Greenberg et al., 1992; Kenessey and Yen, unpublished observations). Both the major and minor forms of neuroblastoma tau shared phosphorylated epitopes (PHF-1, T3P, and NP8) with PHF-tau. Thus, our results strongly suggest that cultured cells and possibly fetal brains contain kinase/phosphatase systems that may be operative in neurons of $\mathrm{AD}$. Moreover, neuroblastoma cells or fetal brains may be a good source for isolation and characterization of enzymes capable of affecting phosphorylation of tau similar to that in PHF-tau.

Exposure of cultured cells to heat stress for 30-60 min led to the loss of immunoreactivity of tau proteins with antibodies to phosphorylated epitopes (PHF-1, T3P, and NP8). Exposure of cultured cells to heat stress also led to a decrease in the molecular weight of tau from $53-58 \mathrm{kDa}$ to $55-45 \mathrm{kDa}$. The changes were unlikely due to proteolysis of the N-end of the tau molecule, since these regions (Alz50 epitope, aa 2-10; E-1 epitope, aa 1933) were detected in the heat-stressed tau. Involvement of pro- teolysis at the C-terminus was also unlikely, since the stressed tau retained the Tau46 epitope (aa 404-441). According to previous studies (Ksiezak-Reding et al., 1990a), the C-terminal of tau is less sensitive to proteolysis than the $\mathrm{N}$-terminus. Further evidence that argues against the involvement of proteolysis was obtained from the studies of cells recovering from heat stress, in which the electrophoretic mobility and immunoreactivity of tau were partially restored after the cells were transferred from the heat-stress condition to $37^{\circ} \mathrm{C}$. Moreover, addition of OA to cells prior to heat stress protected the tau proteins in these cells from changes in electrophoretic mobility and immunoreactivity induced by heat stress. The results indicate that the increase of electrophoretic mobility of heat-stressed tau is related at least in part to dephosphorylation.

Rephosphorylation of dephosphorylated epitopes was found in cells after $2 \mathrm{hr}$ of recovery at $37^{\circ} \mathrm{C}$. At this point in time, only one of the $55-45 \mathrm{kDa}$ bands reacted with antibodies to phosphorylated epitopes. We do not know whether the heat stressinduced dephosphorylation and the recovery-associated rephosphorylation are limited to PHF-1, T3P, and NP8 epitopes. This issue may be resolved by further studies of the immunoreactivity of heat-stressed tau with other antibodies raised to defined phosphorylated epitopes, or analysis of the phosphate content of tau in cells with and without heat stress. The increase of PHF-1, NP8, and T3P immunoreactivities in the recovering state was not likely due to protein synthesis, since similar results were obtained in the presence of protein synthesis inhibitors.

The effect of heat stress on cultured cells was different from that on intact animals. While heat stress apparently did not affect the phosphorylation of Tau-1 epitope in neuroblastoma cells, it has been reported to cause a reduction of Tau-1 immunoreactivity in young adult rats (Papasozomenos and $\mathrm{Su}$, 1991). We do not know the basis for these differences. One possibility might be the difference in species (human vs. rat). Alternatively, this might be a result of differences in the kinase/ phosphatase system between neuroblastoma cells and adult rat brains.

Tau from LAN cells or normal human brains, in contrast to PHF-tau, can readily be detected by Tau-1 antibody without pretreatment with alkaline phosphatase. This difference might be due to a rapid dephosphorylation of the Tau-1 site in nonAD samples. In support of this view is our finding of the phosphorylated Tau- 1 epitope in cells that were treated with OA, an inhibitor to protein phosphatases 1 and $2 \mathrm{~A}$. These phosphatases have been shown to dephosphorylate tau in in vitro studies. The effect of OA on the Tau-1 epitope, however, might also be due to activation of kinase(s), which either directly catalyzes the Tau-1 epitope phosphorylation or acts indirectly through a cascade of actions. OA treatment has been shown to increase protein phosphorylation in cultured cells (Olsson and Belfrace, 1987; Haavik et al., 1989; Haystead et al., 1989) and to activate MAP2 kinases in PC12 cells (Miyasaka et al., 1990). Moreover, tau proteins can be phosphorylated in vitro by MAP kinases (Drews et al., 1992). It remains to be determined if the activation of MAP kinases and/or other kinases in vivo is required for the phosphorylation of Tau-1 epitope in PHF.

OA treatment prevented the PHF-1, T3P, and NP8 epitopes from the dephosphorylation induced by heat stress. Unlike tau from heat-stressed cells (45-60 min), which did not react with PHF-1, T3P, and NP8, tau proteins from OA-treated and heatstressed cells did not lose their reactivity with these antibodies. The results suggest that heat stress might exert its effect by 
stimulation of phosphatase 1 and/or phosphatase $2 \mathrm{~A}$. Alternatively, it might involve inhibition of kinases involved in phosphorylating the sites mentioned above. Comparative analysis of the activity of different kinases and phosphatases in control and stressed cells may resolve this issuc.

\section{References}

Baudier J, Cole RD (1987a) Phosphorylation of tau proteins to a state like that in Alzheimer's brain is catalyzed by a calcium/calmodulindependent kinase and modulated by phospholipids. J Biol Chem 262 : 17577-17583.

Baudier J, Cole RD (1987b) Separation of the different microtubuleassociated tau protein species from bovine brain and their mode II phosphorylation by $\mathrm{Ca}^{2+}$ /phospholipid-dependent protein kinase $\mathrm{C}$. J Biol Chem 262:17584-17590.

Bialojan C, Takai A (1988) Inhibitory effect of a marine-sponge toxin okadaic acid on protein phosphatases. Biochem J 256:283-290.

Braak H, Braak E, Grundke-Iqbal I, Iqbal K (1986) Occurrence of neuropil threads in the senile human brain and in Alzheimer's disease: a third location of paired helical filaments outside of neurofibrillary tangles and neuritic plaques. Neurosci Lett 65:351-355.

Brion JP, Hanger DP, Bruce MT, Couck AM, Flament-Durand J, Anderton BH (1991) Tau in Alzheimer neurofibrillary tangles. N- and C-terminal regions are differentially associated with paired helical filaments and the location of a putative abnormal phosphorylation site. Biochem J 273:127-133.

Casper D, Davies P (1989) Mechanism of activation of choline acetyltransferase in a human neuroblastoma cell line. Brain Res 478:8594.

Cleveland DW, Hwo S-Y, Kirschner MW (1977) Physical and chemical properties of purified tau factor and the role of tau in microtubule assembly. J Mol Biol 116:227-247.

Diaz-Nido J, Serrano L, Avila J (1988) Differential phosphorylation of microtubule proteins by ATP and GTP. Mol Cell Biochem 79:7379 .

Drews D, Lichtenberg-Kraag B, Doring F, Mandelkow EM, Biernat J, Goris J, Doree M, Mandelkow E (1992) Mitogen activated protein (MAP) kinase transforms tau protein into an Alzheimer-like state. EMBO J 11:2131-2138.

Goedert M, Jakes R (1990) Expression of separate isoforms of human tau proteins: correlation with the tau pattern in brain and effects on tubulin polymerization. EMBO J 9:4225-4230.

Goedert M, Spillantini MG, Jakes R, Rutherford D, Crowther RA (1989) Multiple isoforms of human microtubule associated protein tau: sequences and localization in neurofibrillary tangles of Alzheimer's disease. Neuron 3:519-526.

Goedert M, Spillantini MG, Jakes R (1991) Localization of the Alz50 epitope in recombinant human microtubule-associated protein tau. Neurosci Lett 126:149-154.

Goto S, Yamamoto H, Fukunaga K, Iwasa T, Matsukado Y, Miyamoto E (1985) Dephosphorylation of microtubule-associated protein 2, $t$ factor, and tubulin by calcineurin. J Neurochem 45:276-283.

Greenberg SG, Davies P (1990) A preparation of Alzheimer paired helical filaments that displays distinct tau proteins by polyacrylamide gel electrophoresis. Proc Natl Acad Sci USA 87:5827-5831.

Greenberg SG, Davies P, Schein JD, Binder LI (1992) Hydrofluoric acid-treated $\mathrm{tPHF}$ proteins display the same biochemical properties as normal tau. J Biol Chem 267:564-569.

Grundke-Iqbal I, Iqbal K, Quinlan M, Tung Y-C, Zaidi MS, Wisniewski HM (1986) Microtubule-associated protein tau: a component of Alzheimer paired helical filaments. J Biol Chem 261:6084-6089.

Haavik J, Schelling DL, Campbell DG, Anderson KK, Flatmark T, Cohen P (1989) Identification of protein phosphatase $2 \mathrm{~A}$ as the major tyrosine hydroxylase phosphatase in adrenal medulla and corpus striatum: evidence from the effects of okadaic acid. FEBS Letl $251: 36-42$.

Hasegawa M, Arai T, Ihara Y (1990) Immunochemical evidence that fragments of phosphorylated MAP5 (MAP1B) are bound to neurofibrillary tangles in Alzheimer's disease. Neuron 4:909-918.

Haystead TJ, Sim ATR, Carling D, Honnor RC, Tsukitani YM, Cohen $P$, Hardie DG (1989) Effects of the tumor promoter okadaic acid on intracellular protein phosphorylation and metabolism. Nature 337: 78-81.

Himmler A (1989) Structure of the bovine tau gene: alternatively spliced transcripts generate a protein family. Mol Cell Biol 9:13891396.

Himmler A, Drechsel D, Kirschner MW, Martin DW Jr (1989) Tau consists of a set of proteins with repeated C-terminal microtubulebinding domains and a variable $\mathrm{N}$-terminal region. Mol Cell Biol 9:1381-1388.

Ishiguro K, Ihara Y, Uchida T, Imahori K (1988) A novel tubulindependent kinase forming a paired helical filament epitope on tau. J Biochem 104:319-321.

Kanemaru M, Miura R, Hasegawa M, Kuzuhara A, Ihara Y (1992) Fetal-type phosphorylation of the tau in paired helical filaments. $J$ Neurochem 58:1667-1675.

Kidd M (1963) Paired helical filaments in electron microscopy of Alzheimcr's disease. Nature 197:192-193.

Kosik KS, Orecchio LD, Binder LI, Trojanowski JQ, Lee VMY, Lee G (1988) Epitopes that span the tau molecule are shared with paired helical filaments. Neuron 1:817-825.

Ksiezak-Reding H, Dickson DW, Davies P, Yen S-H (1987) Recognition of tau epitopes by anti-neurofilament antibodies that bind to Alzheimer neurofibrillary tangles. Proc Natl Acad Sci USA 84:34103414.

Ksiezak-Reding H, Binder LI, Yen S-H (1988) Immunochemical and biochemical characterization of tau proteins in normal and Alzheimer's disease brains with Alz50 and Tau-1. J Biochem 263:79487953.

Ksiezak-Reding H, Chien C-H, Lee VMY, Yen S-H (1990a) Mapping of the Alz50 epitope in microtubule-associated protein tau. J Neurosci Res 25:412-419.

Ksiezak-Reding H, Binder L, Yen S-H (1990b) Alzheimer disease proteins (A68) share epitopes with tau but show distinct biochemical properties. J Neurosci Res 25:420-430.

Ksiezak-Reding H, Liu W-K, Yen S-H (1992) Phosphate analysis and dephosphorylation of modified tau associated with paired helical filaments. Brain Res 597:209-216.

Laemmli UK (1970) Cleavage of structural proteins during the assembly of the head of bacteriophage T4. Nature 227:680-685.

Lee VM, Balin BJ, Otvos L, Trojanowski JQ (1991) A68 a major subunit of paired helical filaments and derivatized forms of normal tau. Science 251:675-678.

Lindwall G, Cole RD (1984) The purification of tau protein and the occurrence of two phosphorylation states of tau in brain. J Biol Chem 259:12241-12245.

Liu W-K, Ksiezak-Reding H, Yen S-H (1991) Abnormal proteins from Alzheimer's disease brain. Purification and amino acid analysis. $J$ Biol Chem 266:21723-21727.

Liu W-K, Dickson DW, Yen S-H (1992) Heterogeneity of tau proteins in Alzheimer's discase: evidence for increased expression of an isoform and preferential distribution of a phosphorylated isoform in neurites. Am J Pathol 142:387-394.

Lowry OH, Rosenbrough NJ, Farr AL, Randall RJ (1951) Protein measurement with the Folin phenol reagent. J Biol Chem 193:265275.

Miyasaka T, Miyasaka J, Saltiel AR (1990) Okadaic acid stimulates the activity of microtubule associated protein kinase in PC-12 pheochromocytoma cells. Biochem Biophys Res Commun 168:1237-1243.

Morishima-Kawashima M, Arai T, Ogawara M, Takio K, Titani K, Saitoh T, Kosik K, Ihara Y (1991) A possible fetal antigen of $\mathrm{Mr}$ 70,000 in neurofibrillary tangles. Brain Res 554:316-320.

Olsson H, Belfrace P (1987) The regulatory and basal phosphorylation sites of hormone sensitive lipase are dephosphorylated by protein phosphatase-1, 2A, and 2C, but not by protein phosphatase-2B. Eur J Biochem 168:399-405.

Papasozomenos SCH, Su Y (1991) Altered phosphorylation of tau protein in heat-shocked rats and patients with Alzheimer disease. Proc Natl Acad Sci USA 88:4543-4547.

Terry RD, Gonatas NF, Weiss M (1964) Ultrastructural studies in Alzheimer's presenile dementia. Am J Pathol 44:269-297.

Wisniewski HM, Narang HK, Terry RD (1976) Neurofibrillary tangles of paired helical filaments. J Neurol Sci 27:173-181.

Wolozin BL, Pruchnicki A, Dickson DW, Davies P (1986) A neuronal antigen in the brains of Alzheimer patients. Science 232:648-650.

Wood JG, Mirra SS, Pollock NJ, Binder LI (1986) Neurofibrillary tangles of Alzheimer's disease share antigenic determinants with the axonal microtubule-associated protein tau. Proc Natl Acad Sci USA $83: 4913-4917$ 
Yamamoto H, Fukunaga K, Tanaka E, Miyamoto E (1983) $\mathrm{Ca}^{2+}$ - and calmodulin-dependent phosphorylation of microtubule-associated protein 2 and tau factor, and inhibition of microtubule assembly. $J$ Neurochem 41:1119-1125.

Yamamoto H, Fukunaga K, Tanaka E, Miyamoto E (1985) $\mathrm{Ca}^{2+}$ calmodulin-dependent regulation of microtubule formation via phosphorylation of microtubule-associated protein 2, tau factor and tubulin. J Neurochem 44:759-767.
Yamamoto H, Saitoh Y, Fukunaga K, Nishimura H, Miyamoto E (1988) Dephosphorylation of microtubule proteins by brain protein phosphatase 1 and $2 \mathrm{~A}$, and its effect on microtubule assembly. $\mathrm{J}$ Neurochem 50:1614-1623.

Yang S-D, Yu JS, Lai YG (1991) Identification and characterization of ATP $\cdot \mathrm{Mg}$-dependent protein phosphatase activator $\left(\mathrm{F}_{\mathrm{A}}\right)$ as a microtubule protein kinase in the brain. J Protein Chem 10:171-181. 